BANCA D'ITALIA

E U ROS I S T E M A

Questioni di Economia e Finanza

(Occasional Papers)

Autarchy along the distribution

by Silvia Fabiani, Alberto Felettigh and Alfonso Rosolia 

BANCA D'ITALIA

E U R O S I S T E MA

\section{Questioni di Economia e Finanza}

(Occasional Papers)

Autarchy along the distribution

by Silvia Fabiani, Alberto Felettigh and Alfonso Rosolia

Number 580 - November 2020 
The series Occasional Papers presents studies and documents on issues pertaining to the institutional tasks of the Bank of Italy and the Eurosystem. The Occasional Papers appear alongside the Working Papers series which are specifically aimed at providing original contributions to economic research.

The Occasional Papers include studies conducted within the Bank of Italy, sometimes in cooperation with the Eurosystem or other institutions. The views expressed in the studies are those of the authors and do not involve the responsibility of the institutions to which they belong.

The series is available online at www.bancaditalia.it.

ISSN $1972-6627$ (print)

ISSN 1972-6643 (online)

Printed by the Printing and Publishing Division of the Bank of Italy 


\title{
AUTARCHY ALONG THE DISTRIBUTION
}

\author{
by Silvia Fabiani*, Alberto Felettigh* and Alfonso Rosolia*
}

\begin{abstract}
We measure the share of foreign value added embedded in the domestic consumption expenditure of the Italian household sector as a whole and of households along the distribution of consumption expenditure. We find that for each euro spent for consumption by households, almost irrespective of their affluence, about 20 to 40 cents remunerate foreign production factors; around two fifths of this foreign value added originate in other euro-area countries. Because of their heterogeneous bundles, households consume foreign value added through different expenditure items; less affluent ones do so through price-inelastic varieties and necessities.
\end{abstract}

JEL Classification: D39, E21, F42, F45.

Keywords: global value chains, foreign and domestic value added, distribution of households' consumption expenditure, exchange-rate shocks, international policy transmission.

DOI: $10.32057 / 0 . Q E F .2020 .580$

\section{Contents}

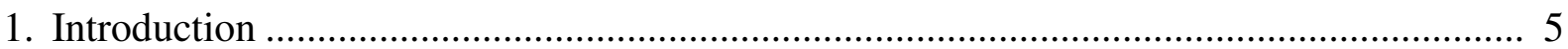

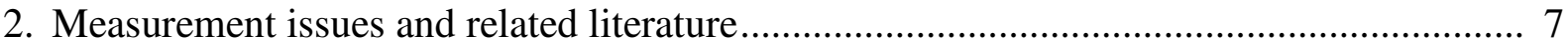

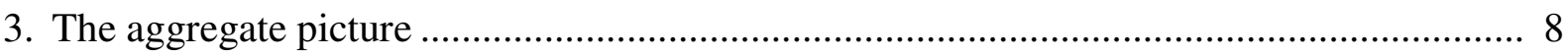

3. Towards the micro picture: data, hurdles and methods ............................................... 11

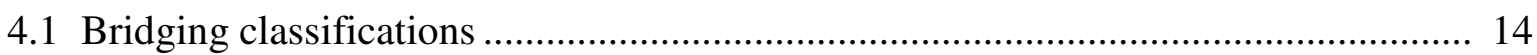

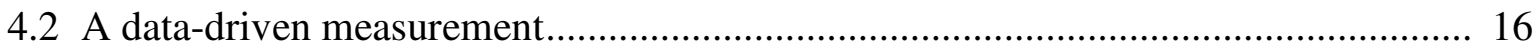

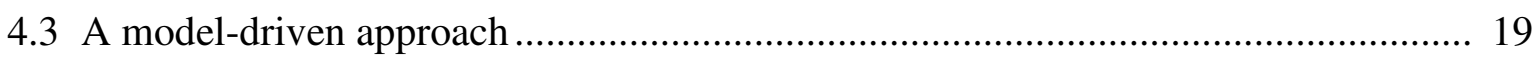

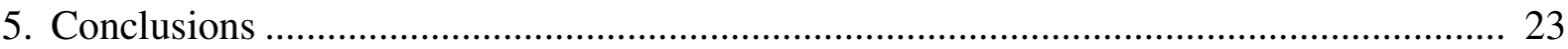

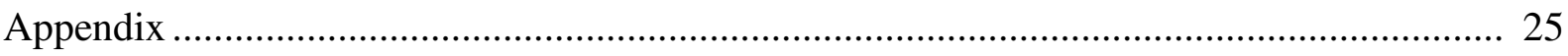

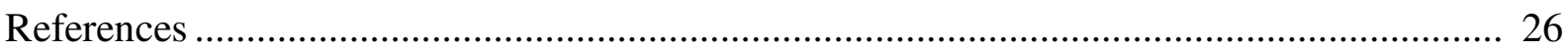

\footnotetext{
* Bank of Italy, Directorate General for Economics, Statistics and Research.
} 



\section{Introduction ${ }^{1}$}

How much domestic and how much foreign value added do Italian households consume?

The answer is relevant for at least two reasons. The first one is the extent to which household consumption feeds into GDP. Indeed, the foreign content embedded in the goods and services bought by consumers rewards by definition foreign factors of production and therefore does not directly contribute to gross domestic product. The second reason relates to the exposure of households to foreign inflation and to exchange-rate movements, through the foreign content of consumption. ${ }^{2}$ Indeed, consumption of domestic productions that use local inputs intensively is more likely to be insulated from these external pressures than consumption of manufactures that rely heavily on imported intermediates (or of final imported goods).

Besides, the amount of foreign value added consumed by individual households is likely to vary with their income and total expenditure because of the heterogeneity in consumption bundles, both in terms of expenditure categories and in terms of "varieties" within such categories. This implies, for example, that income- or demand-support programmes will have different aggregate effects depending on the households (and expenditures) targeted; it also implies that, all else equal, exchange-rate or foreign-price movements will have distributive effects through their differential impact on households' purchasing power.

In this paper, we address these issues and offer evidence on the geographical origin of the value added embedded in Italian household expenditure, both at the aggregate level and along the distribution.

In a globalized world, the foreign value added of domestic consumption is only loosely related to imports of final consumption goods. On the one hand, imports do not entirely consist of foreign value added, as they incorporate themselves a domestic value-added component, to the extent that their production requires (also) domestic intermediates. On the other hand, also domestic final consumption goods incorporate foreign value added, through the underlying foreign intermediate inputs.

We measure the foreign value added content of consumption using the World Input-Output database (WIOD). That is, we start from final consumption expenditure in Italy and trace back, following the production linkages through global value chains (GVCs), how this expenditure is distributed among the various countries' contributions in terms of their value added. Seen in the opposite direction, we record how value added stacks up in subsequent stages of production and distribution around the globe, starting from the most upstream ones to the most downstream ones before final use by households. Our approach thus also accounts for the fact that what households actually pay for their consumption includes an array of mostly domestic services, in the form of transportation, logistics and distribution, wholesale and retail activities.

1 We thank Andrea Brandolini for helpful comments.

2 Such measure is an accounting-based gauge of how large the consequences of exchange-rate movements or foreign inflation could be for domestic consumers. This is admittedly a rough metric, relying on many strong assumptions; in the case of exchange-rate movements, the main ones are: i) all imports are invoiced in foreign currencies, ii) exchangerate shocks translate entirely into import prices, iii) mark-ups and distribution margins are constant and iv) endogenous responses (monetary policy, for instance) and second-round effects do not occur (see Gopinath, 2015). 
Importantly, WIOD allows splitting the foreign value added content of consumption between the component originating in other euro-area economies and that originating elsewhere. This distinction is extremely relevant in light of the policy implications outlined above. On the one hand, the expenditure of the Italian household sector directly propagates to income of other euro-area members through their share of value added embedded in the goods and services bought by Italian consumers; assessing such spillovers sheds light on the interconnections across member countries and on the potential effects of policies that support household incomes and demand at the euro-area level. On the other hand, disentangling the component of domestic consumption that is potentially affected by price developments in other euro-area countries allows, in a euro-area-wide policy perspective, to assess endemic inflationary pressures in the Eurozone. Moreover, belonging to the euro area and sharing a common currency limits the exposure to exchange-rate fluctuations exclusively to the foreign value added generated in countries outside the euro area (and, it could be argued, implies the use of a much stronger and more stable currency than a hypothetical national one had Italy not joined the monetary union).

We explore the distributive dimension of these aspects with two complementary approaches. The first is a data-driven approach, which focuses on how different households allocate their expenditure across consumption categories (e.g. food vs travel), based on the individual data from the Household Budget Survey (HBS) conducted by the Italian National Statistical Institute (Istat). The second is a model-driven approach, accounting for the fact that, within each consumption category (e.g. cars), different households consume varieties of different quality, which we proxy with the product's geographic origin (e.g. German brands vs Chinese brands).

We find that between one and two fifths (depending on the data and method used) of the expenditure of Italy's household sector "buys" foreign value added. In other words, of each euro spent for consumption, about 60 to 80 cents accrue to domestic income, whereas about 20 to 40 cents remunerate foreign production factors. Slightly less than half (around 40 per cent) of this foreign value added originates in other euro-area countries: Italy's participation in the monetary union overall almost halves the share of "consumption at risk", i.e. exposed to foreign pressures trough exchangerate shocks.

The breakdown between the domestic and the foreign content of expenditure is broadly constant along the distribution of households, irrespective of their affluence. However, the geographical origin of the foreign component is heterogeneous: the expenditure of more affluent households flows to a larger extent to euro-area production factors.

We also find significant heterogeneity across the distribution in terms of consumption bundles: our results show that the foreign value added in the expenditure of less affluent households is mainly embedded in price-inelastic varieties and in necessities; the opposite happens for more affluent households. Hence, consumers at the lower end of the distribution have less margins of adjustment in reaction to, for example, external shocks that raise the price of the foreign component of their expenditure. Moreover, compared to households at the higher end of the distribution, they buy relatively more extra-euro area value added for each euro spent on consumption: this means that they are relatively less insulated from exchange-rate movements while they benefit relatively more from euro-area membership thanks to the global status of the euro and to the strength and stability that go with it. 
Relative to the existing macro literature, our analysis extends the concept of import content of consumption (see for instance Burstein, Eichenbaum and Rebelo, 2005; Gopinath, 2015) to a more encompassing measure of foreign content of consumption. Relative to the micro-based studies that delve with distributional issues, our paper is, to the best of our knowledge, the first to focus on Italian households and it complements a literature that is rather scant even when the perspective is widened beyond Italy. Indeed, while the Covid-19 pandemic, the recent resurgence of protectionist policies and the escalation of trade disputes have revived the academic debate on countries' exposure to tradeinduced shocks - from 'supply chain contagion' 3 to new tariffs, to possible exchange-rate shocks due for example to Brexit, to the geographical allocation or reallocation of production stages - few quantitative studies have so far dealt with the quantification of household exposure to such risks, which we summarize by the foreign value added content of consumption, and with their distributional implications.

The paper is organised as follows. Section 2 exposes the major measurement challenges our analysis needs to face, and casts it in the context of the existing literature. Section 3 presents our quantitative assessment of the foreign content of consumption at the aggregate level. Section 4 first spells the details of how we bridge the aggregate picture into the micro dimension and then analyses how the content of foreign value added varies across households, depending on the composition of their consumption bundles, i) in terms of expenditure categories, on the basis of HBS data, and ii) in terms of the geographical origin of "varieties" within expenditure categories, on the basis of a modelbased exercise. Section 5 wraps-up our main conclusions.

\section{Measurement issues and related literature}

The assessment of countries' exposure to trade-driven shocks and, more in general, of their dependence on foreign productions, is subject to strong measurement challenges. Indeed, due to the international fragmentation of production, standard trade statistics are incapable of fully capturing cross-country supply and demand relationships.

The quantitative literature has dealt with these issues through the use of inter-country Input-Output Tables such as the WIOD or the OECD-WTO TiVA database, that allow tracking value added along the supply chain from the country of origin to the country of final use. ${ }^{4}$ The studies based on such data have mostly focused on the measurement of the domestic vs foreign value-added content of exports or on identifying the countries where exports are ultimately absorbed, or on measuring the domestic value added "activated" by another country' final demand through its imports. With few exceptions, very limited research effort has been devoted to the use of these statistical instruments for understanding how international production inter-linkages impact on the split between the domestic and the foreign value added embodied in a country's internal demand components.

Among the existing studies, Hale and Hobijn (2016) find, on the basis of gross trade flows, that about 14 per cent of the expenditure by US consumers goes to imported goods and services. As an example of how biased the picture depicted by standard trade statistics can be, due to not fully

3 In the words of Baldwin and Freeman (2020), the economic impact of national lockdown measures to contain the Covid-19 outburst spread worldwide - like the virus itself - due to GVCs: "Supply-chain contagion will amplify the direct supply shocks as manufacturing sectors in less affected nations find it harder and/or more expensive to acquire the necessary imported industrial inputs from the hard-hit nations, and subsequently from each other."

4 See Koopman et al. (2014), Cappariello and Felettigh (2015), Borin and Mancini (2015). 
capturing cross-country supply and demand relationships, a later study (Hale et al, 2019) shows that, once the analysis is performed in value-added terms and the origin of value added is accounted for, the foreign content of US consumption results as being lower than previously estimated, just over 10 per cent. Evidence for European countries is rather scant: Bourgeois and Briand (2019) quantify the foreign content of French household consumption at just below 20 per cent; Chandler et al (2018) focus on the UK consumer-price basket, computing an import intensity that ranges between 16 and 20 per cent depending on price index considered (and thus on the underlying consumption basket).

Even less emphasis has been put in the literature on the distributional aspects related to the heterogeneous impact of global value chains on individual household consumption bundles, through their different foreign value-added content. Recent studies on the heterogeneous exposure of households to trade or trade-induced shocks focus either on specific events or on model-based estimations, and only consider the import rather than the foreign component of consumption. Cravino and Levchenko (2017), for example, study the impact of (large) exchange-rate devaluations on the cost of living at different points on the income distribution, whereas Fajgelbaum and Khandelwal (2016) and Atkin et al. (2018) examine the distributional impact of economic integration across consumers by modelling income elasticities and demand non-homotheticities. A few empirical papers more closely related to ours have recently been triggered by the Brexit referendum. Breinlich et al. (2017) show that the pound depreciation following the referendum led to higher inflation for products with a larger import share in consumer expenditure; they find that the inflation burden was shared evenly throughout the income distribution but unevenly across regions. In a related study, Breinlich et al. (2016) focus on how prices would react after Brexit due to changes in trade barriers, concluding that the negative consequences of higher import prices would be slightly harder for middle-income households than for the richest and for the poorest.

\section{The aggregate picture}

How much does the Italian economy pay out to other countries for the final consumption of its households? For correctly answering the question it is not sufficient to compute the fraction of consumption expenditure that is absorbed by final products made abroad, i.e. imported, as opposed to products that are "made in Italy". Stated differently, it is not sufficient to consider only the direct import content of consumption. Conceptually, three more ingredients have to be included in order to quantify the foreign content of consumption.

First, as already mentioned in the introduction, one also needs to take into account the indirect import content, namely the imported intermediate inputs used in domestically produced final goods. ${ }^{5}$ Second, in connection with the ramification of GVCs, both the direct and the indirect import contents need to be properly measured, by acknowledging their content of Italian value added in the form of exported domestic intermediates that were used abroad to produce the goods and services that were then imported into Italy. Third, the value of imported final goods is measured at the border, while consumption expenditure is measured "at the store shelf", hence including an array of mostly domestic services, in the form of transportation, logistics and distribution, wholesale and retail activities.

5 Hereafter, by "domestically-produced final goods" we mean final goods that have not been imported; since nowadays virtually no good is made using only domestic inputs, what matters for our distinction is that the last productive stage of the final good took place in Italy, namely that the final good was not imported as such (i.e. already as a final good). 
Our approach takes simultaneously into account all these three factors, since it allows disentangling the domestic and the foreign value added embedded in each consumption good and service. We use the November 2016 release of WIOD data at current prices and US dollars for the period 2000-2014; the database covers 43 countries (including the 28 European Union member states) and 59 product groups at the 2-digit CPA (version 2) classification detail. WIOD data are crucial for tracing back, by following the production linkages through GVCs, all countries that contributed (in value-added terms) to the foreign component. We compute the latter by implementing the Hypothetical Extraction approach of Los, Timmer and De Vries (2016). ${ }^{6}$

The distinction between the direct import component and the foreign component of consumption is quantitatively very relevant. Indeed, according to gross trade data, the fraction of imported goods and services in Italy's consumer spending was just above 11 per cent in 2014 (Tab. 1 left-hand-side panel). This figure doubles when the geographical origin of the value-added content of both domestically produced and imported final goods is taken into account: the share of foreign value added consumed by Italian households rises by around 10 percentage points, reaching 21.1 per cent (Tab. 1 right hand side panel). In other words, out of the 878.2 billion euros spent by Italian households in 2014 for final consumption in WIOD data, 186 billion were ultimately paid out to foreign productive inputs.

Table 1 - Composition of Italy's household consumption expenditure (1) (percentages)

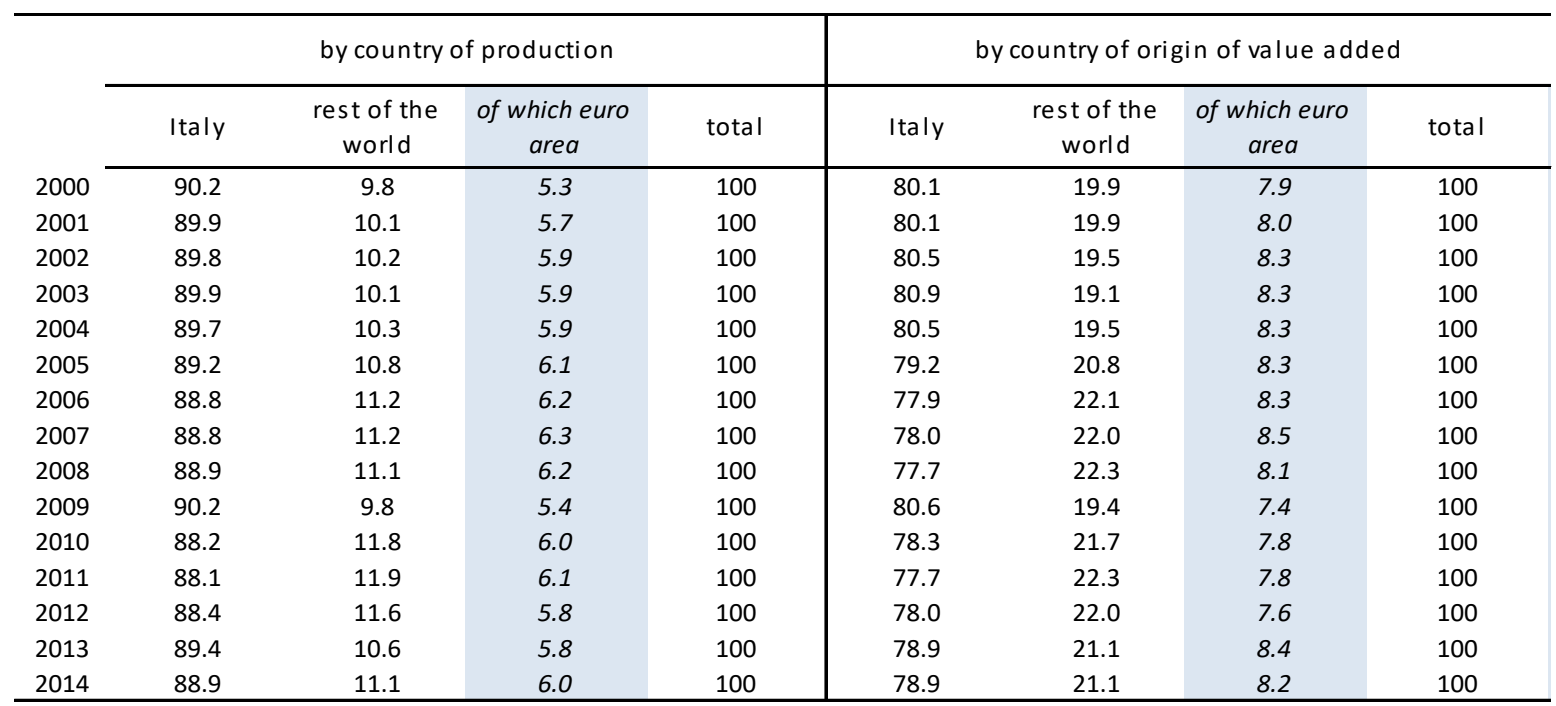

Source: authors' computations on WIOD data (November 2016 release) at current prices and exchanges rates. (1) The panel labelled "by country of production" keeps track, for each product in the consumption bundle, of the supplying country; the panel labelled "by country of origin of value added" keeps track of all the countries that contributed with their value added to the various products in the consumption bundle.

In the 2000-2014 period, the incidence of foreign goods and services in consumption expenditure recorded a gradual increase until the outburst of the global trade collapse, diminished strongly in 2009 and recovered thereafter. The share in 2014 is close to the peak it had reached in 2008.

6 In a nutshell, this methodology "extracts" the amount of a country's value added that is embedded in consumption expenditure of Italian households as the difference between that country's aggregate value added - as computed in the original WIOD table - and the corresponding value added computed in a counterfactual ("hypothetical") table where the consumption of Italian households has been zeroed out. 
More than one third of the foreign content in 2014, namely 8.2 per cent of consumption expenditure, can be traced back to value added that originated in euro-area countries (other than Italy): Measured in terms of gross imports, the euro-area weight is lower ( 6.0 per cent), but it accounts for more than half of the import content of consumption. However, final consumption products imported from euro-area partners actually incorporate a large part of extra-euro area countries' value added. ${ }^{7}$

Table 2 zooms into the breakdown of Italy's consumption expenditure in 2014 by country of origin of value added, isolating the most important contributors. It also provides a comparison with the figures computed for the other three major euro-area countries. Domestic value added accounts for a slightly lower share of household expenditure in Germany and France than in Italy and Spain; among the foreign contributors, the weight of the euro area ranges between roughly 8 and 10 per cent across the four countries, followed by China and the US. The fraction of consumption that can be traced back, in value-added terms, to the UK is rather low (between 0.8 and 1.5 per cent), still higher than the weight of value added originating in Russia and Switzerland.

The last row of Table 2 presents results for the US based on computations by Hale et al (2019). The comparison between these figures suggests that euro-area countries' households consume a much larger share, at least twice as large in fact, of foreign value added than US households: in Italy 21.1 per cent against only 10.7 per cent. Unsurprisingly, the weight of value added originating from the euro area is very modest in the case of US consumption (1.2 per cent, less than one tenth of the overall foreign content).

Table 2 - Composition of household consumption expenditure in 2014 in the four main euro-area economies and in the US, by country of origin of value added (percentages)

\begin{tabular}{|c|c|c|c|c|c|c|c|c|c|}
\hline & \multirow[b]{2}{*}{ Domestic } & \multicolumn{7}{|c|}{ Foreign } & \multirow[b]{2}{*}{ TOTAL } \\
\hline & & Euro area & UK & US & China & Russia & Switzerland & $\begin{array}{c}\text { Other } \\
\text { countries }\end{array}$ & \\
\hline France & 75.4 & 9.7 & 1.5 & 2.0 & 1.8 & 0.5 & 0.7 & 8.4 & 100 \\
\hline Germany & 74.1 & 8.8 & 1.3 & 2.2 & 2.3 & 0.9 & 0.9 & 9.5 & 100 \\
\hline Italy & 78.9 & 8.2 & 1.1 & 1.3 & 1.5 & 0.7 & 0.5 & 7.9 & 100 \\
\hline Spain & 79.1 & 7.8 & 0.8 & 1.1 & 1.6 & 0.5 & 0.4 & 8.7 & 100 \\
\hline US (1) & 89.3 & 1.2 & n.a. & n.a. & 1.7 & n.a. & n.a. & 7.8 & 100 \\
\hline
\end{tabular}

Source: authors' computations on WIOD data (November 2016 release) at current prices and exchanges rates. Euro area net of the reporting country. (1) Hale et al. (2019).

As expected, the average share of household expenditure that can be traced back to non-domestic origins is very heterogeneous across types of goods and services. For Italy the foreign content is generally higher in manufactured goods, around 55 per cent in 2014 (about 20 percentage points more than in 2000) and much lower in services (11 per cent, almost unchanged since 2000; Tab. 3 ).

Euro-area countries account for more than 40 per cent of the foreign value added embedded in Italian consumers' expenditure for manufactures, consistently with the evidence provided in studies of "factory Europe" (Amador, Cappariello and Stehrer, 2015; Baldwin and J. Lopez-Gonzalez, 2015).

7 The relevance of Chinese value added has increased significantly over time, while that of large economies such as the UK and the USA has remained modest. Table 2 will present some detailed figures. 
The weight of euro-area value added is instead relatively low in the category of raw materials and energy products.

Table 3 - Sectoral composition and foreign content of Italy's household consumption expenditure (percentages)

\begin{tabular}{|c|c|c|c|c|c|c|}
\hline & \multicolumn{3}{|c|}{2000} & \multicolumn{3}{|c|}{2014} \\
\hline & $\begin{array}{l}\% \text { composition } \\
\text { of household } \\
\text { consumption }\end{array}$ & $\begin{array}{l}\% \text { foreign value } \\
\text { added content }\end{array}$ & $\begin{array}{l}\text { of which } \\
\text { euro area }\end{array}$ & $\begin{array}{l}\% \text { composition } \\
\text { of household } \\
\text { consumption }\end{array}$ & $\begin{array}{l}\% \text { foreign value } \\
\text { added content }\end{array}$ & $\begin{array}{l}\text { of which } \\
\text { euro area }\end{array}$ \\
\hline raw materials and energy prod. & 8,1 & 32,3 & 9,0 & 6,6 & 41,6 & 12,5 \\
\hline manufactures (excl. energy prod.) & 28,7 & 35,9 & 16,6 & 17,6 & 55,7 & 23,3 \\
\hline construction & 1,2 & 15,7 & 6,1 & 1,2 & 16,6 & 6,4 \\
\hline services & 62,1 & 11,0 & 3,7 & 74,6 & 11,2 & 4,2 \\
\hline TOTAL & 100 & 19,9 & 7,9 & 100 & 21,1 & 8,2 \\
\hline
\end{tabular}

Source: authors' computations on WIOD data (November 2016 release) at current prices and exchanges rates.

Table A1 in Appendix shows that, among the different manufacturing categories, the foreign component is especially large (more than two-thirds) for the expenditure in chemical and pharmaceutical products, electronics and electrical equipment, gasoline and fuels, as well as motor vehicles. Notably, expenditures in traditional "made in Italy" productions, such as textile, wearing apparel and leather products are for almost three-quarters related to external value added, whereas those in manufactured food products, beverage and tobacco for almost half. A few categories of expenditures among services are also characterized by a sizeable intensity of foreign value added: air transport, architectural and engineering activities, R\&D services for more than two-thirds, activities auxiliary to financial and insurance services for about 40 per cent. Origin wise, only for textiles, wearing apparel and leather products, within manufactures, is the weight of China almost at par with that of the euro area, though it is substantial also for electronics and for electrical equipment. UK value added accounts for a significant fraction of the expenditure in activities auxiliary to financial and insurance services and in R\&D services, whereas the US is a prominent source of the foreign value added embedded in architectural and engineering services.

\section{Towards the micro picture: data, hurdles and methods}

Using WIOD data, we have traced the value added embedded in Italy's aggregate household expenditure back to the countries of origin. We now consider explicitly the heterogeneity across households and try to quantify how the foreign value added consumed by the household sector distributes across different consumers. To this end, the ideal dataset - that would enable replicating at the individual household level the quantitative strategy pursued at the aggregate level in the previous section - should contain sufficiently detailed descriptions of expenditure bundles for a representative sample of households, hence allowing tracing single items to their production inputs and supplier countries. However, available microdata are far from ideal. For one thing, even at its most detailed level, data collected by household budget surveys do not allow to distinguish expenditures by country of origin and quality, two dimensions known to be widely heterogeneous across households. For example, it is impossible to tell apart expenditures on a luxury German car 
from the purchase of an Italian clunker. The aggregate WIOD data only partly share this limitation, in that they do not allow distinguishing products and services based on their quality. To overcome these drawbacks we follow two complementary empirical strategies, each with its own merits and limitations.

First, we adopt a purely data-driven approach. We complement data on individual expenditures collected in the Italian household budget survey (HBS) with the product-level measures of foreign value added content developed in the previous section, and we estimate household-specific shares of foreign value added in consumption. This approach has the merit of using observed data on household expenditure but it is limited by the lack of consistency between the classification of consumption expenditure items (COICOP) adopted in the HBS and that of products used in the WIOD. We overcome this hurdle by making assumptions on the linkages between the two classifications.

Second, we adopt a model-driven approach (section 4.3). We exploit the aggregation properties of a standard theoretical representation of individual demand functions to infer household-specific budget shares from the observation of the composition of aggregate consumption expenditure and of the household's relative income. Applied to WIOD data, this approach has the merit of making full use of available information. In particular, by defining a consumption item as the combination of a product category and a supplier country (à la Armington, 1969) we can partly address the fact that, within product categories, households consume varieties of different quality, which we proxy with the product's geographical origin. The merits of this approach come at the cost of making strong assumptions on household behaviour and of using a coarse product classification for consumption items.

Since these approaches combine different data sources, it is useful to start by clarifying the main discrepancies between the HBS-based and the WIOD-based composition of the household sector expenditure.

In general, HBS and WIOD use different definitions, implement different classifications for the goods and services that households consume and look at a different population of agents. We review these three aspects in turn.

WIOD data are sourced from National Accounts (NAs) and hence are broadly aligned with them. ${ }^{8}$ In turn, NAs do estimate household consumption expenditure based on HBS, but the latter is just one among a variety of sources, which are further complemented with imputation procedures; ${ }^{9}$ these inputs then undergo an overall re-balancing in order to guarantee internal consistency. HBS data are instead disseminated as collected and are thus subject to the usual caveats of survey-based statistics, like measurement error and under-reporting issues.

Concerning the reference population, WIOD/NAs data refer to expenditure in Italy by resident and foreign consumers, thus including the expenses of inbound international tourists. HBS targets a different population, as it collects the expenditure of resident consumers only, be it incurred in Italy

8 The statement holds for data at basic prices, which is the only evaluation available in WIOD data. In principle, these should be identical to NA data: they differ because the latest WIOD tables were released in November 2016 and thus do not reflect the revisions that NAs have introduced thereafter.

9 Imputations refer to consumption expenditures that are not paid "out of the pocket". Examples are imputed rental payments of homeowners and health or education public services that are provided for free or at administrative fees below market price. 
or abroad (thus including the expenses of outbound national tourists). ${ }^{10} \mathrm{We}$ are bound to accept the assumption that both sets of data are a good proxy for the variable we are interested in, namely the expenditure in Italy by Italian households, which unfortunately cannot be disentangled given the available information.

As for classifications, WIOD provides the breakdown of consumption expenditure by CPA products, while NAs are available with a breakdown both by CPA and by 3-digit COICOP (Classification of Individual Consumption by Purpose) and HBS uses the 4-digit COICOP.

With these caveats in mind, Figure 1 compares the composition of household consumption expenditure for Italy in NAs and HBS in 2017 across ad-hoc macro categories that we have rearranged (mainly) from the standard 2-digit COICOP classification:

- food, beverages and tobacco: we group food and non-alcoholic beverages together with alcoholic beverages and tobacco (COICOP codes 01 and 02);

- clothing and footwear (03);

- housing services, furniture, appliances: we group housing (04) - excluding actual and imputed rents $(04.1,04.2)$ and electricity, gas and other fuels (04.5) - with furniture and furnishings (05) and with telephone services (08.3);

- paid rents (04.1);

- imputed rents (04.2);

- ICT (Information and Communication Technology): we group telephone equipment (08.2) with audio-visual, photographic and information processing equipment (09.1);

- recreation, restaurants, hotels: we group recreation and culture (09) - excluding audio-visual, photographic and information processing equipment (09.1) - with restaurants and hotels (11);

- transports (excluding fuels), which corresponds to purchases of goods and services for the operation of personal transport equipment (07) bar fuels and lubricants (07.2.2);

- energy and fuels: we group fuels and lubricants for personal transport equipment (07.2.2) with electricity, gas and other fuels (04.5);

- health (06);

- education (10);

- other goods and services, grouping code 12 (miscellaneous goods and services, which includes personal care, personal effects, insurance and financial services) and postal services (08.1).

Panel A in Figure 1 considers all categories and compares the percentage composition of consumption expenditure in NAs with that in HBS in 2017. The starker difference is the lower share of imputed rents in NAs; this is consistent with the fact that NAs, as mentioned above, include the expenditure in Italy of foreigners, which are unlikely to be imputed rental payments.

Imputed rents is, however, a category we want to abstract from: since we are primarily interested in the foreign content of household expenditure, we see as appropriate the exclusion of items that do not correspond to actual payments. Panel B in Figure 1 provides the comparison between the two sources after excluding imputed rents: as these account, due to the high homeownership rate, for a large share of resident household consumption (over 20 per cent in HBS), their exclusion raises by about one fourth the expenditure shares on the other items.

10 Tourists tend to spend disproportionately in hotel accommodation and restaurants as well as in transport services. Indeed, according to the latest Bank of Italy's Survey on international tourism, almost two-thirds of the expenditure by foreign tourists in Italy is concentrated in accommodation and restaurants, and one-tenth in transport services. Similar shares hold for Italian tourists abroad. 
Figure 1 - Household consumption in National Accounts and in the Household Budget Survey (percentages; data for 2017)
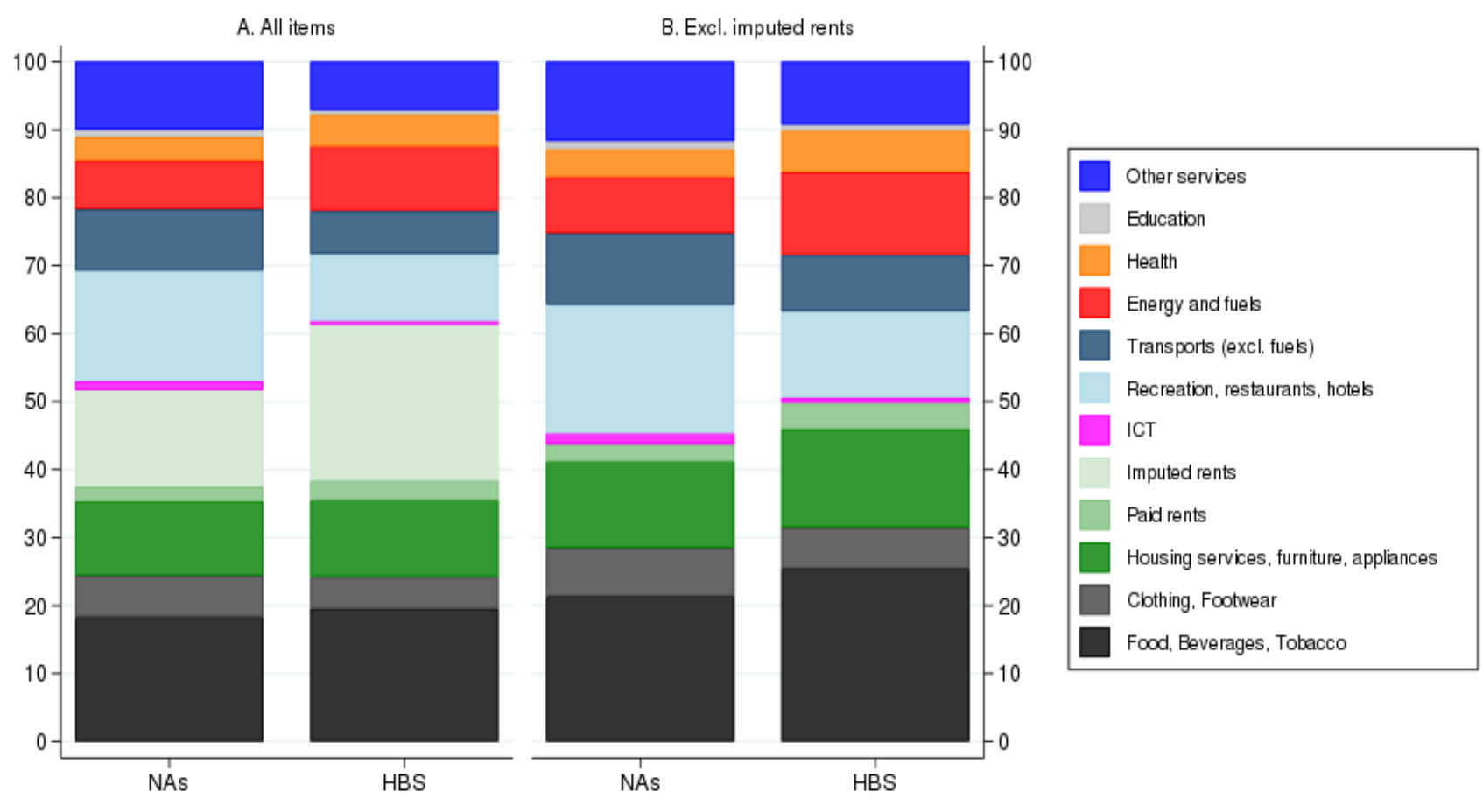

Source: authors calculations on Istat data (National Accounts and HBS).

\subsection{Bridging classifications}

Given the different classifications adopted by WIOD and HBS, the joint use of the two sources as in our data-driven approach requires mapping CPA products into 4-digit COICOP categories. Unfortunately, no public data for bridging the two classifications is available for Italy, whereas the UK Office for National Statistics (ONS) publishes a very detailed cross-over (or bridge) matrix that allocates CPA consumption (2-digit CPA 2008) across the various COICOP categories (4-digit COICOP 1999). ${ }^{11}$ Even if the bridge matrix we use is based on UK rather than Italian data, insofar as it can be interpreted as a "technology" that maps CPA products into COICOP items we do not expect, at least to a first approximation, major differences with the confidential analogous matrix used by Istat to compile NAs.

Notice that in this mapping neither the CPA leg nor the COICOP one display a geographical breakdown. To exemplify, in this framework German and French cars are simply "Cars", produced using the same combination of CPA products, again irrespective of their geographical origin. This implies, in particular, that using the mapping published by ONS implicitly assumes that imported COICOP goods and services are produced according to the same technology (CPA combinations) as domestic ones.

With this caveat in mind, we compute the share $s_{c}$ of foreign value added in each COICOP consumption category $c$ in HBS as follows. For each $c$, we combine each of the shares $m_{p}$ of foreign value added in CPA product $p$ (56 product categories, computed from WIOD) with the corresponding

11 For each CPA product, the cross-over table specifies its incidence in each COICOP category. 
weight $q_{p c}$ that, according to the UK cross-over matrix, product $p$ bears in category $c$, with the property $\Sigma_{p} q_{p c}=1$ holding:

$$
s_{c}=\sum_{p} m_{p} q_{p c}
$$

As for the country of origin of value added, a similar algebra holds: it suffices to replace the foreign value-added share $m_{p}$ with the country-specific share $m_{p i}$ of foreign value added originating from country $i$ embedded in product $p$. The weighted sum of these shares across expenditure categories each $s_{c}$ being assigned the weight of category $c$ in overall expenditure - gives the share of foreign value added in aggregate household consumption.

Panel A in Table 4 compares the results obtained with those based on WIOD/NAs (already discussed in Section 3). It shows that the differences between the two sources appearing in Figure 1 carry over to the share of foreign value added in aggregate household consumption and to its decomposition by country of origin of value added. In particular, the foreign value-added content of total consumption computed from HBS is higher than that computed from WIOD/NAs (28.7 against 21.1 per cent) and climbs up to nearly 37 per cent if imputed rents are excluded. ${ }^{12}$ Of this foreign value added, less than half originates from other euro-area countries (14.7 per cent, as opposed to 22 per cent from the rest of the world).

Table 4 - Origin of value added in consumption expenditure: WIOD/NAs and HBS (percentages)

\begin{tabular}{|c|c|c|c|c|c|}
\hline & Italy & $\begin{array}{c}\text { Total } \\
\text { Foreign }\end{array}$ & Euro area & Extra-EA & Total \\
\hline \multicolumn{6}{|l|}{ A. Total consumption } \\
\hline WIOD/NAs (1) & 78.9 & 21.1 & 8.2 & 13.1 & 100 \\
\hline HBS 2017 - all items (2) & 71.3 & 28.7 & 11.5 & 17.2 & 100 \\
\hline HBS 2017 - excl. imputed rents (2) & 63.2 & 36.8 & 14.7 & 22.0 & 100 \\
\hline \multicolumn{6}{|l|}{ B. Main expenditure categories (2) } \\
\hline Food, beverages, tobacco & 56.5 & 43.5 & 22.1 & 21.4 & 100 \\
\hline Clothing, footwear & 30.8 & 69.2 & 15.6 & 53.6 & 100 \\
\hline Housing services, furniture, appliances & 70.2 & 29.8 & 11.8 & 17.9 & 100 \\
\hline Paid rents & 98.0 & 2.0 & 0.8 & 1.2 & 100 \\
\hline Imputed rents & 98.1 & 1.9 & 0.8 & 1.1 & 100 \\
\hline ICT & 31.1 & 68.9 & 23.0 & 45.9 & 100 \\
\hline Recreation, restaurants, hotels & 79.8 & 20.2 & 7.7 & 12.4 & 100 \\
\hline Transports (excl. fuels) & 49.8 & 50.2 & 23.0 & 27.2 & 100 \\
\hline Energy and fuels & 49.2 & 50.8 & 12.9 & 37.9 & 100 \\
\hline Health & 57.7 & 42.3 & 20.2 & 22.0 & 100 \\
\hline Education & 97.7 & 2.3 & 0.8 & 1.5 & 100 \\
\hline Other services & 77.0 & 23.0 & 9.4 & 13.5 & 100 \\
\hline
\end{tabular}

Source: authors' calculations on: (1) WIOD 2014; (2) HBS 2017, WIOD 2014, UK ONS crossover table.

The foreign content varies quite significantly across expenditure categories (panel B): it is nearly 70 per cent in clothing and footwear and in ICT; between 40 and 50 per cent in energy, transports, food and health; around one fourth in recreation and leisure activities, housing related expenditures and remaining services; it is almost nil in rents and education. Except for food and beverages, whose foreign value-added content originates almost equally within and outside the euro area, all other

12 The impact of such exclusion on WIOD/NAs statistics cannot be evaluated, as imputed rents are not a separate CPA product in WIOD and NAs data are only published by 3-digit COICOP, which is not a sufficiently detailed level of information for using the cross-over matrix. 
consumption items contain value added originating to a relatively larger extent from extra-euro area countries.

\subsection{A data-driven measurement}

We start out by documenting the heterogeneity of consumption bundles across the household distribution using the micro dimension of the HBS. Figure 2 reports, for each of the main categories of goods and services described in section 4.1, the expenditure share of households ranked according to their total equivalent consumption, for twentieths of the distribution. ${ }^{13}$ Imputed rents represent a large share of expenditure, which decreases only mildly along the distribution due to the widespread ownership of the main residence; consistently, less "affluent" 14 households (on the left-hand side of the distribution) display a higher share of paid rents. The share of food and beverages as well as that of fuel and energy decrease with affluence (consistently with Engle's law), while the opposite holds for the incidence of recreational and transportation goods, services (other than ICT), clothing and footwear. Once again, these patterns are amplified when we exclude imputed rents (Fig. 2, panel B), which is the option we follow in the rest of the analysis as we focus on the composition of actual, "out-of-the-pocket" expenditures.

Figure 2 - Consumption bundles by total equivalent expenditure (percentages; data for 2017)

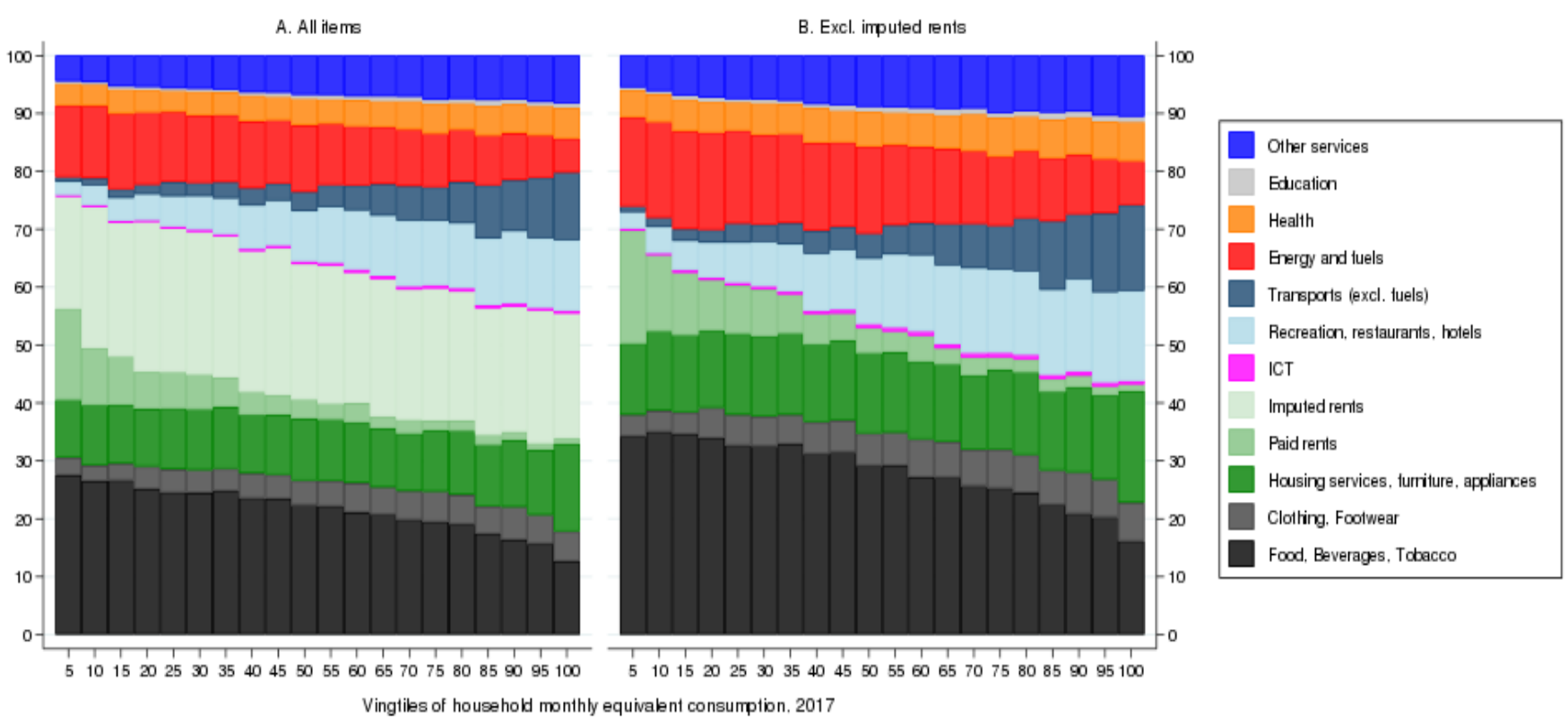

Source: authors' calculations on WIOD (November 2016 release) data for 2014, HBS data for 2017 and UK ONS crossover table.

13 Since the distribution of income, which measures the stream of resources available for consumption and savings, is not available in HBS public files, we resort to a second-best measure of economic wellbeing (equivalent consumption) that accounts for the potential economies of scale in household expenditure deriving from household size and demographic structure. Since HBS public files provide only very coarse information on the age of household members (below 18, 18-34, 35-64, 65 and more), we are prevented from using the standard OECD equivalence scale that differentiates members according to their age. We therefore adopt a simple equivalence scale and adjust total household expenditure dividing it by the square root of the number of family members.

14 Throughout the analysis, we use the term "affluent" although we are not looking at the income distribution. 
In summary, less affluent households display, as expected, a higher share of expenditure in necessary items, which are typically characterised by a lower direct (compensated or uncompensated) elasticity of demand to prices. For example, Rondinelli (2015) estimates that in 2012 the compensated price elasticity of food consumption was -0.5 while that of more easily avertable restaurant expenditure was nearly triple (-1.5).

To assess the heterogeneity of the foreign content of consumption across twentieths, we exploit the full micro-level detail of HBS data and combine the composition of individual consumption bundles (panel B of Figure 2) with the share of foreign value added in each consumption category (summarized in panel B of Table 4). In detail, we compute for each household $h$ the fraction $x^{h}$ of foreign value added in overall expenditure:

$$
x^{h}=\left(\Sigma_{c} S_{c} v^{h}\right) / V^{h}
$$

where $v_{c}^{h}$ is the level of expenditure of household $h$ on category c (at the 4-digit COICOP level), $s_{c}$ is the share of foreign value added in category $c$ (as defined in section 4.1) and $V^{h}$ is household $h$ overall expenditure.

Results are shown in Figure 3, which presents the share of foreign value added by twentieths of the distribution, along with the composition of foreign value added across consumption macrocategories. ${ }^{15}$

Figure 3 - Foreign value added in consumption expenditure (percentages; data for 2017)

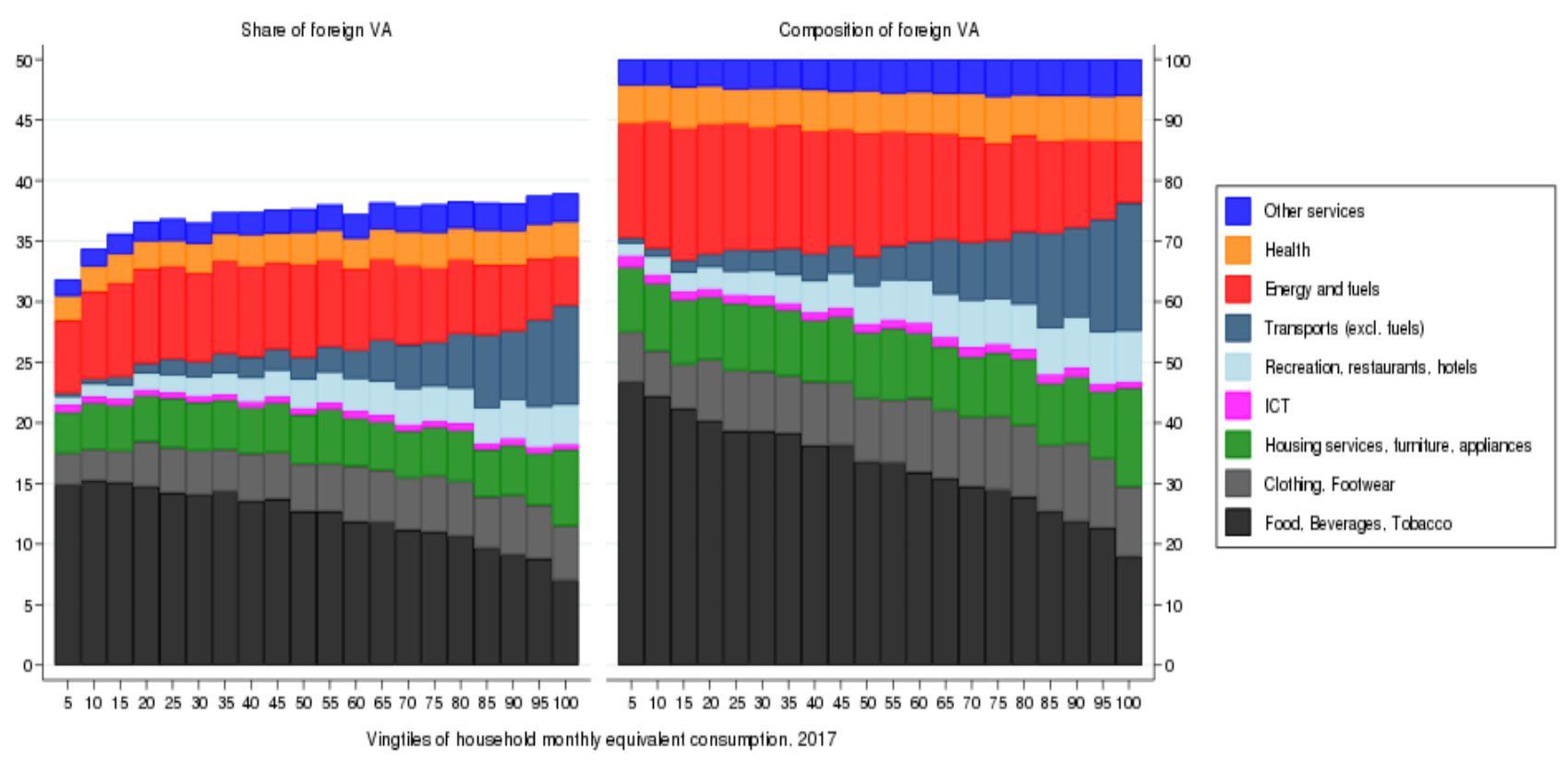

Source: authors' calculations on WIOD (November 2016 release) data for 2014, HBS data for 2017 and UK ONS crossover table.

15 While imputed rents are excluded to begin with, results for paid rents and education are not shown, as their foreign content is negligible both in aggregate terms and along the distribution. 
Overall, the incidence of foreign value added is broadly stable (apart from the very first twentieths) along the distribution, around 37 per cent (panel A). A closer look at its composition by expenditure category, however, reveals striking differences across households (panel B). Two thirds of the foreign value added consumed by households in the bottom fifth of the distribution are traceable to food and beverages (42 per cent) and energy and fuels ( 21 per cent); the share of these items in foreign value added consumed by households in the upper fifth is only one third (respectively, 21 and 13 per cent). On the contrary, more than one fourth of the foreign value added consumed by affluent households is embedded in recreational, travel and transport goods and services, against only about 5 per cent among poorer ones. Similar results hold also if we break down the population by broad age groups and by main income source.

To gauge the heterogeneity, along the distribution, of the geographical allocation of foreign value added, Figure 4 splits the latter into that originating from euro-area countries (except Italy; panel A) and that originating from the rest of the world (panel B). ${ }^{16}$

Although the two components are overall broadly constant along the distribution (excluding the initial twentieths), with about 15 per cent of value added stemming from the euro area and 22 per cent from elsewhere, the heterogeneity by origin across consumption categories has a significant distributional dimension. Indeed, the extra-euro area value added embedded in expenditures for energy and fuels as well as for food and beverage - items characterized by a low price-elasticity of demand - has a larger share in the consumption bundle of less affluent households.

Figure 4 - Origins of foreign value added in consumption expenditure (percentage shares of foreign value added in consumption expenditure; data for 2017)

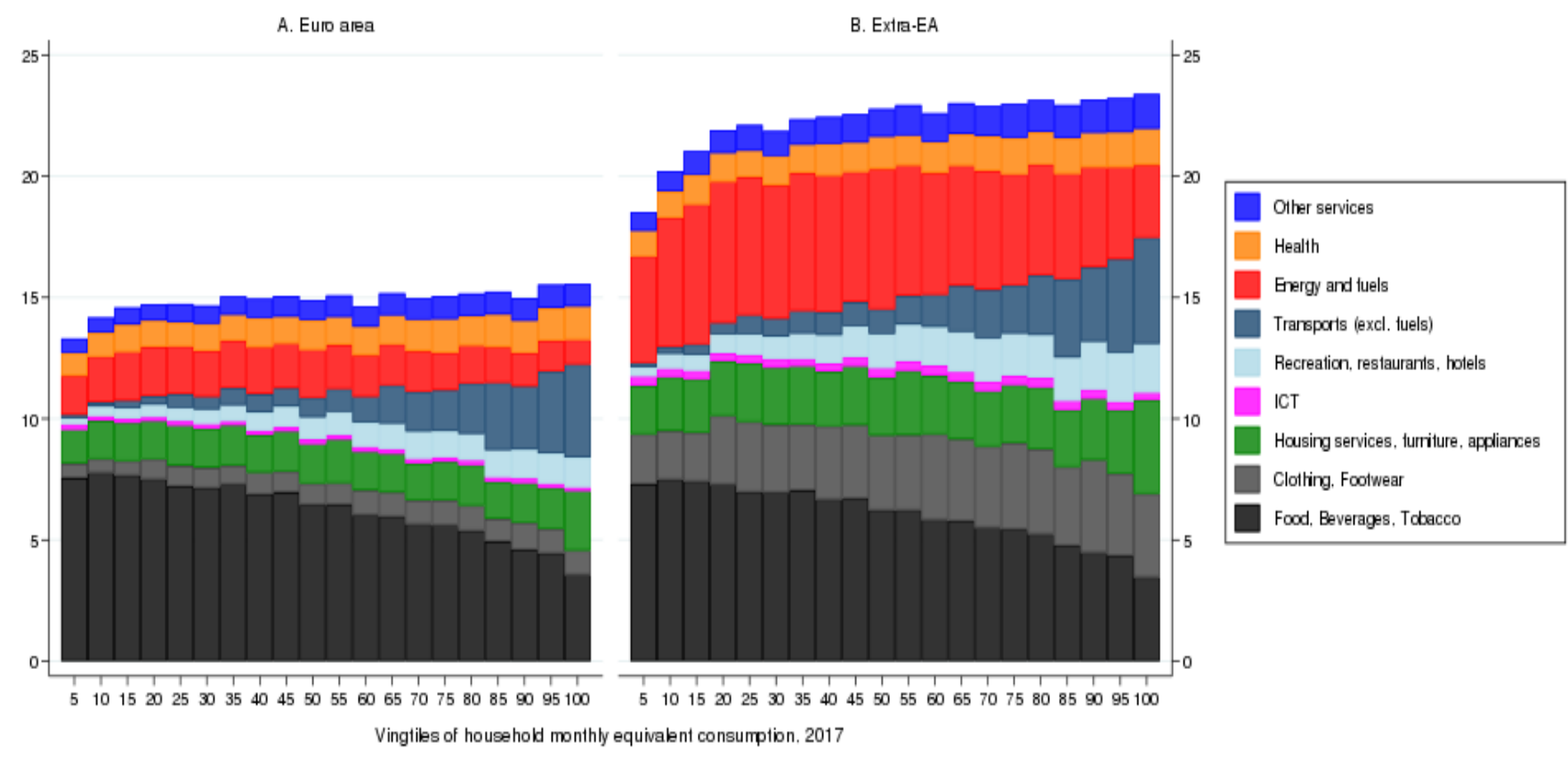

Source: authors' calculations on WIOD (November 2016 release) data for 2014, HBS data for 2017 and UK ONS crossover table.

16 The sum of the two components corresponds to the shares shown in the left-hand side of Fig. 3. 
In summary, according to our micro-based computations based on HBS data, slightly more than one third of the expenditure of Italian households - once imputed rents are excluded - "buys" foreign value added; this overall share does not change substantially with individual consumption levels, but its distribution across expenditure categories and foreign origin varies dramatically. Indeed, households in the lower part of the distribution spend proportionately more on energy and food products, which not only are characterized by a larger content of foreign value added (especially for the component originating from countries outside the euro area), but are also relatively inelastic to prices.

\subsection{A model-driven approach}

The different shares of foreign value added across households detected by the data-driven approach stem only from differences in the composition of expenditure across COICOP categories. However, while providing a highly detailed description of consumption expenditures, HBS data is likely to miss other relevant dimensions of heterogeneity across the household distribution, connected to variability within consumption categories. ${ }^{17}$ Possibly, the most relevant such dimension is quality; for example, luxury sport cars and cheap economy ones fall in the same 4-digit COICOP category. This is clearly a relevant limitation for our analysis, as less affluent households are likely to select lower-quality varieties within a given consumption category and since the foreign content of lowquality varieties is likely to be very different from that of high-quality varieties. For instance, the incidence of foreign value added in cheap garments made in East Asia is presumably much higher than the incidence in luxury made-in-Italy garments; vice-versa, the incidence in an Italian economy car may be much lower than the incidence in luxury German cars. To complicate further the picture, we notice that the foreign content in expenditure is unlikely to be monotonically related to quality also across categories, given the consumption patterns of Italian households. For example, both lowquality textiles and high-quality cars are likely to have a higher foreign content than the opposite varieties within the same categories.

To address this limitation, we draw inspiration from the empirical trade literature that has established a strong association between quality and the products' geographic origin (for example, Fajgelbaum, Grossman, Helpman (2011), Feenstra and Romalis (2014)). Building on this notion, in the following we expand the analysis of households' expenditure patterns to consider also the geographic origin of each product they consume by adapting to our purposes the approach proposed by Fajgelbaum and Khandelwal (2016) to study the distributive effects of trade.

Fajgelbaum and Khandelwal (2016) embed an Almost Ideal Demand System (AIDS; Deaton and Muellbauer, 1980) into a standard multisector model of international trade. Relevant to our purposes, this allows estimating how consumption expenditure, on a given category and at a given point of the household income distribution, is distributed across qualities/origins; the corresponding foreign value added contents by quality/origin can then be computed from WIOD data, a dimension that we were not able to exploit in the previous section.

17 Cravino and Levchenko (2017) for instance show that following the devaluation of the Mexican peso in 1994, inflation for the consumption basket of households in the bottom decile of the income distribution was nearly 40 percentage points higher than for the basket of those in the top decile and that heterogeneous price developments within narrow product categories account for about half of this difference. 
More formally, consider a generic consumption item $j$ (only later shall we associate it with a product-origin pair); AIDS implies that for household $h$, the expenditure share on $j$ can be written as:

$$
s_{j}^{h}=\alpha_{j}+\sum_{k=1}^{J}\left[\gamma_{j k} \ln \left(p_{k}\right)\right]+\beta_{j} \ln \left[y_{h} / \alpha(P)\right],
$$

where $y_{h}$ is household $h$ total expenditure, $a(P)$ is a well-defined price aggregator of the vector price $P$ of individual prices $\left\{p_{k}\right\}_{k=1, \ldots, J}, \gamma_{j k}$ is the cross price (semi)elasticity between items $j$ and $k$, and $\beta_{j}$ is the income (semi)elasticity of item $j$, assumed to be identical across households. Parameters satisfy $\Sigma_{\mathrm{j}} \alpha_{\mathrm{j}}=1, \Sigma_{\mathrm{j}} \beta_{\mathrm{j}}=\Sigma_{\mathrm{j}} \gamma_{\mathrm{jk}}=0$ and $\gamma_{\mathrm{jk}}=\gamma_{\mathrm{kj}}$. This demand system can be aggregated at the market level so that $S_{j}$, the aggregate expenditure share on item $j$, can be interpreted as the behaviour of a representative agent:

$$
S_{j}=\alpha_{j}+\sum_{k=1}^{J}\left[\gamma_{j k} \ln \left(p_{k}\right)\right]+\beta_{j} \ln [\boldsymbol{y} \exp (T) / \alpha(P)],
$$

where $\mathbf{y}$ is the average household expenditure and $T$ is the Theil index of the associated distribution.

Fajgelbaum and Khandelwal (2016) embed this demand system in a simple standard international trade model in which, to start with, consumption items are identified by a product-origin pair $(g, i)$. The authors then assume that:

(i) exporting item $(g, i)$ (that is, product $g$ from country $i$ ) to country $n$ entails an iceberg trade $\operatorname{cost} t_{g i}{ }^{n}\left(t_{g i}{ }^{n}>1, t_{g i}{ }^{i}=1\right)$; perfect competition then implies that prices in country $n$ are related to prices in country $i$ by $p_{g i}{ }^{n}=p_{g i}{ }^{i} t_{g i}{ }^{n}$;

(ii) labour is the only factor of production and its productivity $Z_{g i}$ is product-country specific;

(iii) wage per efficiency unit in country $i$ is equalized across products at $w_{i}=p_{g i}{ }^{i} Z_{g i}$;

(iv) the distribution of units of labour efficiency across households is country-specific;

(v) households spend all their labour income;

(vi) cross-price elasticities $\gamma$ are assumed to be zero across products and constant within products across origins.

These assumptions and the model equilibrium conditions yield an estimable gravity equation. It relates the aggregate household expenditure share for item $(g, i)$ - i.e. for product $g$ from country $i-$ in country $n$ to the geographic and sectoral distribution of world output, to the structure of bilateral trade costs and to features of the income distribution in country $n^{18}$. This equation can be estimated on WIOD data, thus exploiting the origin-product detail. With respect to the previous analysis based on HBS data, this additional flexibility comes at the cost of losing detail on consumption items, from 4-digit COICOP to 2-digit CPA.

We replicate the estimates of Fajgelbaum and Khandelwal (2016) on (as close as possible to) their original dataset. Importantly, this includes a "reference WIOD table" obtained as the average of the November-2013 vintage of WIOD tables for the years 2005 to 2007, while in the previous sections of this paper we used the new (November 2016) vintage of WIOD tables.

18 Specifically, equations (27) and (45) in Fajgelbaum and Khandelwal (2016) are, respectively, the theoretical specification stemming from the model and the specification empirically implemented; the latter embeds a specific parametrization of trade costs, an explicit choice for income deflators and a parametric assumption about cross-country tastes across sectors and exporters. We direct to their paper for further technical details. 
For our purposes, all we need from this estimation are the income (semi)elasticities $\beta_{j}$ appearing in equation [1]; since index $j$ now should be thought of as spanning all product-origin pairs $(g, i)$, we switch to notation $\beta_{g i}$ for clarity. These estimates are flexible enough to allow for, say, a negative income elasticity of the demand for textiles imported from China and a positive one for those imported from France. They enable us to compute item-specific expenditure shares for any household and to pinpoint him in the income distribution. Indeed, equations [1] and [2] can be rearranged, after substituting the item- $j$ index with the product-origin pair index $(g, i)$, as

$$
s_{g i}^{h}=S_{g i}+\beta_{g i} \ln \left[\frac{y_{h}}{\boldsymbol{y} \exp (T)}\right],
$$

By plugging-in estimated values (denoted by a hat), the estimated expenditure share of household $h$ on any product-origin pair $(g, i)$ can be easily obtained as a simple function of his "relative income" (and of the observable aggregate share $S_{g i}$ ):

$$
\hat{s}_{g i}^{h}=S_{g i}+\hat{\beta}_{g i} \ln \left[\frac{y_{h}}{\boldsymbol{y} \exp (T)}\right] .
$$

For each household $h$ the fraction $x^{h}$ of foreign value added in overall expenditure is then computed as:

$$
x^{h}=\frac{\sum_{g, i}\left(\hat{s}_{g i}^{h} f_{g i}\right)}{V^{h}},
$$

where $V^{h}$ is household $h$ overall expenditure and $f_{g i}$ is the foreign value added content of expenditure in product $g$ sourced from country $i$, computed from the "reference WIOD table" used by Fajgelbaum and Khandelwal. This empirical approach yields a relationship between expenditure shares on $(g, i)$ combinations and household relative income. To map the latter into twentieths of the distribution of equivalent consumption, we resort to the Bank of Italy's Survey of Household Income and Wealth. Specifically, for each twentieth of the distribution of equivalent consumption in such survey, we compute the ratio between the equivalent income of households in the specific twentieth and the overall mean equivalent income. We then use this ratio for each consumption twentieth to compute the specific twentieth's expenditure shares in equation [3].

The results of this exercise are presented in Table 5 and Figure 5. They both group expenditure items by product-origin $(g, i)$ into two distinct categories, based on whether they display a negative (necessities) or positive (luxuries) income elasticity $\left(\beta_{g i}\right)$; for each of these two categories, the foreign value added content is then split depending on whether it originates in the euro area (except Italy) or outside.

Table 5 presents the average share of foreign value added embedded in household total expenditure, while Figure 5 displays its distribution for twentieths of equivalent consumption. ${ }^{19}$

19 Notice that the figures reported in Table 5 and those that can be recovered from Figure 5 may slightly differ. This reflects the fact that Table 5 is computed from observed aggregate expenditure shares and foreign value-added content of each ( $g . i)$ pair obtained from WIOD tables. Figure 5, instead, combines observed aggregate data and estimated income elasticities to recover consumption-twentieth specific expenditure shares and the associated content of foreign value added. In some cases, this procedure may lead to negative expenditure shares. As in Fajegelbaum and Khandelwal (2016), we read this as evidence of constrained choices and follow their procedure to achieve nonnegative expenditure shares on all items in each twentieth. The iterative procedure they propose (see their Appendix A) is applied independently to each twentieth and amounts to evenly redistributing the negative shares across expenditure items initially attracting non-negative expenditure shares. 
Table 5 - Foreign value added by origin and income elasticity

(percentages)

\begin{tabular}{lccc}
\hline & \multicolumn{3}{c}{$\begin{array}{c}\text { Share of foreign value added in } \\
\text { consumption expenditure }\end{array}$} \\
\cline { 2 - 4 } & $\begin{array}{c}\text { From the } \\
\text { euro area }\end{array}$ & $\begin{array}{c}\text { From outside } \\
\text { the euro area }\end{array}$ & Overall \\
\cline { 2 - 4 } Necessities & 15.9 & 19.9 & 37.8 \\
Luxuries & 12.0 & 9.3 & 21.3 \\
Total & 12.5 & 10.7 & 23.2 \\
\hline
\end{tabular}

Source: authors' calculations. See text for details and data sources.

Figure 5 - Foreign value added by origin and income elasticity along the distribution (percentage share of foreign value added in consumption expenditure)

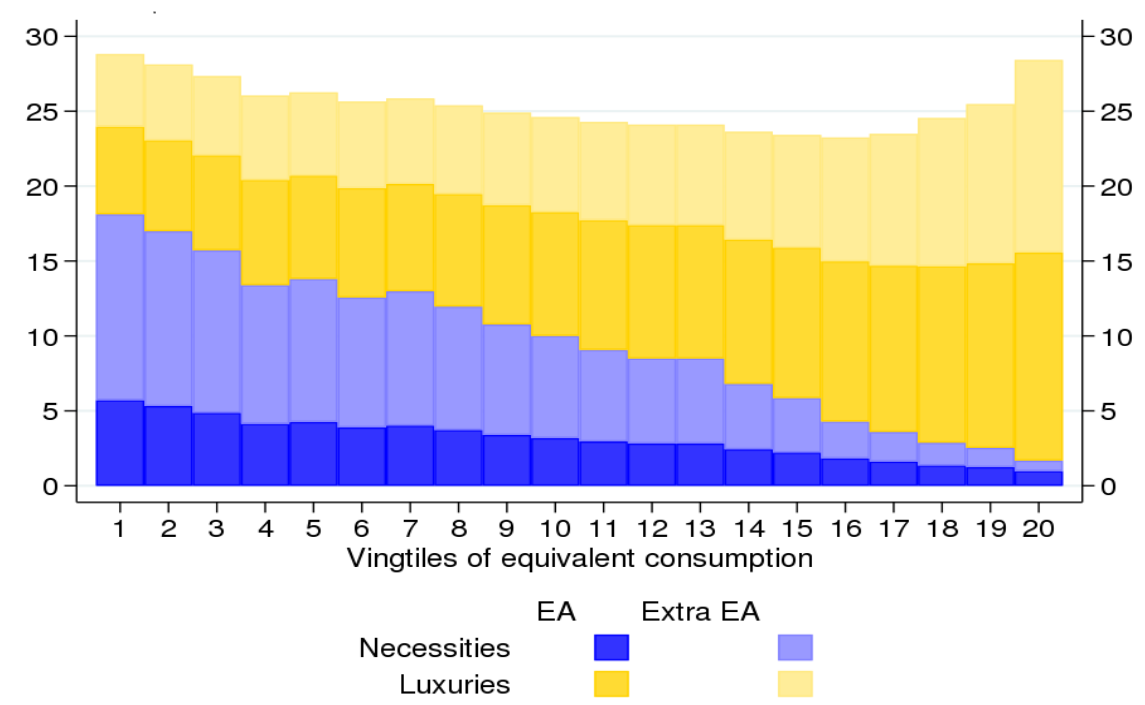

Source: authors' calculations. See text for details and data sources.

Notes: EA and Extra EA indicate foreign value added originating in euro-area countries (other than Italy) and extra euro-area countries, respectively.

The overall share of foreign value added in consumption expenditure resulting from our estimates - slightly above 23 per cent (on average between 2005 and 2007) - is broadly comparable to the average that can be computed, for the same years, from Table 1. Figure 5 shows that this overall share, again, does not vary much across households. There is, however, significant heterogeneity along the distribution both in terms of consumption bundles (necessities vs luxuries) and in terms of origin of foreign value added. As for the latter, on average each euro spent on necessities embeds nearly 20 cents of value added originating from outside the euro area and 16 cents of valued added from other euro area countries; for luxuries, these figures drop down to about 9 and 12 percent, respectively (Tab. 5). As for the heterogeneity in consumption bundles, while expenditure by households in the last twentieth of the distribution consists of luxuries for 97 per cent, the corresponding share is only 28 per cent for households in the first twentieth. Hence, less affluent households are relatively more exposed to global production chains through their expenditure on necessities while more affluent ones through their expenditure on luxuries. Moreover, over two thirds of the foreign value added consumed by less affluent households through their expenditure on 
necessities originates outside the euro area while that consumed by more affluent ones through luxuries is rather evenly split between the two foreign origins.

\section{Conclusions}

This paper moves from the consideration that items consumed by households are the result of global production chains. Because of the heterogeneity in consumption bundles across households and in supply chains across consumption items, different households are likely to consume different fractions of foreign value added. In other words, a different fraction of each euro spent by each type of household flows abroad to remunerate foreign production factors.

The implications are twofold. On the one hand, households display a differential exposure to foreign shocks, in particular those affecting the price of consumption goods and services either through exchange-rate movements or through foreign price developments. On the other hand, the extent to which individual expenditure contributes to domestic and foreign aggregate incomes varies across households.

We explore these issues by exploiting a broad range of sources and methods. We heavily rely on the fact that WIOD tables allow to compute the overall foreign value-added content of each euro spent on a given consumption item and to allocate it among the countries that generated it.

Our calculations show that, at the aggregate level, between one and two fifths of Italian household expenditure "buy" foreign value added. All our results suggest that this share is broadly constant across households with different levels of consumption.

These findings bear important implications. For instance, they quantify in 60 to 80 cents the direct impact on domestic GDP of each euro spent in Italy on income- or private consumption- support programmes. Similarly, they unveil that only 60 to 80 per cent of aggregate household consumption is exposed to the inflationary pressures that originate abroad.

Heterogeneity across consumers does instead matter in terms of the geographical composition of the foreign value added embedded in consumption: the share of expenditure flowing to euro-area production factors (i.e. "buying" foreign value added generated by euro-area countries other than Italy) is lower for less affluent households. We also unveil a significant heterogeneity across the distribution in terms of consumption bundles, namely in terms of which expenditure items account for the largest portion of foreign value added: the expenditure of less affluent households embeds a larger share of foreign value added through more price-inelastic varieties and through necessities.

The implications of this heterogeneity are especially relevant when assessing the potential effects of exchange-rate movements, which directly affect only the portion of foreign value added originating outside the euro area. Indeed our results imply that households at the lower end of the distribution have less margins of adjustment in reaction to, for example, an exchange-rate shock that raises the price of the foreign component of their consumption.

Our analysis shows that euro-area membership contributes both to shield Italian consumers from exchange-rate shocks and - we believe - to reduce their size. Indeed, we find that around 40 per cent of the foreign value added content of consumption originates in euro-area countries (other than Italy) and therefore is not subject to exchange-rate fluctuations. As for the size of shocks, the euro is a global currency, which plausibly warrants that it is much more stable (and stronger) than a 
hypothetical national currency had Italy not joined the monetary union. Importantly, the benefits of these two mechanisms are different across the household distribution. We find that more affluent households buy more euro-area value added for each euro they spend on consumption; this implies that they benefit relatively more from the direct effect of the common currency. Less affluent households, on the contrary, buy more extra-euro area value added for each euro spent on consumption; hence, they benefit relatively more from the global status of the euro and the strength and stability that go with it. 


\section{Appendix}

\section{Table A1 - Foreign content of household consumption expenditure by sector and country of origin of value added}

(percentages)

Household consumption expenditure by sector

Crop and animal production, hunting and related service activities Forestry and logging

Fishing and aquaculture

Mining and quarrying

Manufacture of food products, beverages and tobacco

Manufacture of textiles, wearing apparel and leather products

Manufacture of wood and of products of wood, exc. furniture

Manufacture of paper and paper products

Printing and reproduction of recorded media

Manufacture of coke and refined petroleum products

Manufacture of chemicals and chemical products

Manufacture of basic pharmaceutical prod. and preparations

Manufacture of rubber and plastic products

Manufacture of other non-metallic mineral products

Manufacture of basic metals

Manufacture of fabricated metal prod., exc. machinery and equipment

Manufacture of computer, electronic and optical products

Manufacture of electrical equipment

Manufacture of machinery and equipment n.e.c.

Manufacture of motor vehicles, trailers and semi-trailers

Manufacture of other transport equipment

Manufacture of furniture; other manufacturing

Repair and installation of machinery and equipment

Electricity, gas, steam and air conditioning supply

Water collection, treatment and supply

Sewerage; waste collection, treatment and disposal activities

Construction

Wholesale and retail trade and repair of motor vehicles and motorcycles

Wholesale trade, exc. of motor vehicles and motorcycles

Retail trade, exc. of motor vehicles and motorcycles

Land transport and transport via pipelines

Water transport

Air transport

Warehousing and support activities for transportation

Postal and courier activities

Accommodation and food service activities

Publishing activities

Motion pict., video and telev. production, sound recording and music publ.

Telecommunications

Computer programming, consultancy, information services

Financial service activities, exc. insurance and pension funding

Insurance, reinsurance and pension funding, exc. compulsory social security

Activities auxiliary to financial services and insurance

Real es tate activities

Legal and accounting; head offices; management consultancy

Architectural and engineering activities

Scientific research and development

Advertising and market research

Other professional, scientific and technical activities

Administrative and support service activities

Public administration and defence; compulsory social security

Education

Human health and social work activities

Other service activities

Activities of households as employers; activities of households for own us

TOTAL

\begin{tabular}{|c|c|c|c|c|c|c|c|c|}
\hline \multirow{3}{*}{$\begin{array}{c}\text { expenditure } \\
\text { share }\end{array}$} & \multicolumn{8}{|c|}{ country of origin of value added } \\
\hline & \multirow{2}{*}{ Italy } & \multirow{2}{*}{$\begin{array}{c}\text { rest of } \\
\text { the world }\end{array}$} & \multirow[b]{2}{*}{ euro area } & \multicolumn{3}{|c|}{ of which } & \multirow[b]{2}{*}{ others } & \multirow[b]{2}{*}{ total } \\
\hline & & & & UK & US & China & & \\
\hline 1.83 & 66.5 & 33.5 & 13.9 & 0.6 & 2.0 & 1.1 & 15.9 & 100 \\
\hline 0.04 & 91.5 & 8.5 & 2.7 & 0.4 & 0.4 & 0.3 & 4.7 & 100 \\
\hline 0.17 & 35.0 & 65.0 & 26.2 & 2.1 & 8.1 & 1.1 & 27.5 & 100 \\
\hline 0.71 & 84.0 & 16.0 & 5.1 & 0.6 & 1.0 & 1.1 & 8.1 & 100 \\
\hline 7.06 & 55.0 & 45.0 & 23.5 & 1.3 & 1.9 & 1.3 & 17.1 & 100 \\
\hline 2.82 & 27.0 & 73.0 & 16.2 & 1.5 & 1.9 & 15.1 & 38.2 & 100 \\
\hline 0.20 & 71.9 & 28.1 & 11.0 & 0.7 & 1.2 & 3.0 & 12.1 & 100 \\
\hline 0.34 & 64.1 & 35.9 & 16.2 & 1.3 & 2.2 & 1.6 & 14.5 & 100 \\
\hline 0.07 & 72.0 & 28.0 & 10.4 & 1.8 & 2.2 & 1.9 & 11.7 & 100 \\
\hline 1.90 & 27.7 & 72.3 & 17.4 & 1.3 & 3.4 & 1.8 & 48.4 & 100 \\
\hline 0.66 & 33.6 & 66.4 & 34.8 & 2.5 & 3.6 & 3.0 & 22.5 & 100 \\
\hline 0.42 & 22.9 & 77.1 & 40.2 & 4.6 & 9.6 & 2.1 & 20.6 & 100 \\
\hline 0.55 & 50.4 & 49.6 & 22.7 & 1.9 & 2.3 & 4.7 & 18.1 & 100 \\
\hline 0.41 & 67.4 & 32.6 & 11.3 & 1.1 & 1.4 & 3.3 & 15.6 & 100 \\
\hline 0.18 & 51.7 & 48.3 & 14.9 & 1.8 & 2.3 & 7.4 & 22.0 & 100 \\
\hline 0.35 & 63.0 & 37.0 & 13.9 & 1.2 & 1.9 & 5.8 & 14.4 & 100 \\
\hline 0.71 & 23.2 & 76.8 & 24.7 & 3.1 & 4.4 & 14.0 & 30.6 & 100 \\
\hline 0.45 & 38.4 & 61.6 & 21.2 & 1.4 & 1.7 & 16.2 & 21.0 & 100 \\
\hline 0.32 & 62.8 & 37.2 & 16.0 & 1.5 & 1.9 & 4.5 & 13.4 & 100 \\
\hline 1.89 & 30.9 & 69.1 & 34.3 & 3.0 & 2.4 & 3.2 & 26.3 & 100 \\
\hline 0.25 & 44.3 & 55.7 & 18.5 & 2.9 & 6.6 & 6.1 & 21.5 & 100 \\
\hline 0.92 & 33.3 & 66.7 & 25.8 & 2.6 & 2.5 & 12.0 & 23.8 & 100 \\
\hline 0.06 & 72.2 & 27.8 & 12.5 & 1.1 & 1.4 & 1.4 & 11.2 & 100 \\
\hline 1.95 & 73.0 & 27.0 & 8.0 & 0.9 & 1.5 & 0.9 & 15.8 & 100 \\
\hline 0.50 & 84.1 & 15.9 & 5.4 & 0.9 & 1.2 & 0.6 & 7.9 & 100 \\
\hline 1.00 & 81.9 & 18.1 & 7.4 & 1.5 & 1.9 & 0.8 & 6.6 & 100 \\
\hline 1.18 & 83.4 & 16.6 & 6.4 & 0.8 & 0.9 & 1.0 & 7.5 & 100 \\
\hline 2.46 & 81.3 & 18.7 & 8.6 & 1.1 & 1.0 & 0.9 & 7.2 & 100 \\
\hline 7.06 & 79.2 & 20.8 & 9.6 & 1.6 & 1.3 & 0.7 & 7.5 & 100 \\
\hline 9.78 & 93.0 & 7.0 & 2.6 & 0.5 & 0.5 & 0.3 & 3.1 & 100 \\
\hline 3.01 & 81.4 & 18.6 & 6.2 & 0.6 & 1.3 & 0.6 & 9.8 & 100 \\
\hline 0.64 & 70.7 & 29.3 & 8.7 & 1.0 & 1.9 & 1.0 & 16.7 & 100 \\
\hline 0.77 & 36.9 & 63.1 & 19.5 & 3.4 & 7.9 & 3.2 & 29.1 & 100 \\
\hline 1.09 & 78.4 & 21.6 & 8.0 & 1.0 & 1.5 & 0.8 & 10.3 & 100 \\
\hline 0.09 & 74.6 & 25.4 & 6.2 & 2.0 & 8.7 & 0.8 & 7.9 & 100 \\
\hline 9.35 & 88.4 & 11.6 & 4.0 & 0.5 & 0.7 & 0.5 & 5.9 & 100 \\
\hline 0.42 & 75.4 & 24.6 & 9.0 & 1.5 & 2.4 & 0.9 & 10.8 & 100 \\
\hline 0.54 & 73.1 & 26.9 & 13.5 & 2.5 & 4.7 & 0.6 & 5.7 & 100 \\
\hline 1.79 & 81.8 & 18.2 & 6.0 & 2.1 & 2.9 & 0.9 & 6.3 & 100 \\
\hline 0.28 & 83.3 & 16.7 & 6.6 & 2.1 & 1.6 & 0.7 & 5.8 & 100 \\
\hline 1.73 & 88.5 & 11.5 & 4.5 & 2.0 & 1.9 & 0.2 & 2.9 & 100 \\
\hline 1.85 & 88.4 & 11.6 & 3.5 & 1.7 & 1.3 & 0.3 & 4.8 & 100 \\
\hline 0.23 & 58.7 & 41.3 & 10.9 & 17.5 & 7.9 & 0.4 & 4.6 & 100 \\
\hline 18.39 & 98.1 & 1.9 & 0.8 & 0.2 & 0.1 & 0.1 & 0.7 & 100 \\
\hline 0.47 & 71.3 & 28.7 & 10.2 & 2.5 & 2.4 & 7.1 & 6.6 & 100 \\
\hline 0.11 & 37.6 & 62.4 & 27.9 & 6.1 & 13.5 & 0.8 & 14.2 & 100 \\
\hline 0.01 & 27.1 & 72.9 & 19.9 & 12.1 & 1.6 & 0.8 & 38.4 & 100 \\
\hline 0.01 & 60.7 & 39.3 & 8.7 & 1.9 & 1.1 & 0.6 & 27.0 & 100 \\
\hline 0.26 & 84.9 & 15.1 & 4.7 & 3.1 & 0.9 & 0.6 & 5.9 & 100 \\
\hline 1.18 & 74.2 & 25.8 & 7.8 & 5.0 & 1.2 & 0.7 & 11.2 & 100 \\
\hline 0.25 & 91.0 & 9.0 & 2.6 & 0.3 & 1.6 & 0.2 & 4.3 & 100 \\
\hline 1.40 & 97.7 & 2.3 & 0.8 & 0.2 & 0.2 & 0.1 & 1.0 & 100 \\
\hline 2.64 & 91.0 & 9.0 & 3.6 & 0.7 & 0.9 & 0.5 & 3.4 & 100 \\
\hline 5.08 & 88.3 & 11.7 & 4.4 & 1.2 & 0.8 & 0.7 & 4.7 & 100 \\
\hline 2.19 & 100.0 & 0.0 & 0.0 & 0.0 & 0.0 & 0.0 & 0.0 & 100 \\
\hline 100.00 & 78.9 & 21.1 & 8.2 & 1.1 & 1.3 & 1.5 & 9.1 & 100 \\
\hline
\end{tabular}

Source: authors computations on WIOD data at current prices and exchange rates. Figures in red indicate values above the corresponding mean, reported in the last row. Pink-shaded cells highlight values above 10 per cent. 


\section{References}

Amador, J., R. Cappariello, and R. Stehrer (2015), “Global Value Chains: A View from the Euro Area", ECB Working Paper Series, No. 1761, March.

Armington, P. (1969), “A Theory of Demand for Products Distinguished by Place of Production”, IMF Staff Papers No 16: 159-78.

Atkin, D., B. Faber and M. Gonzalez-Navarro (2018), "Retail Globalization and Household Welfare: Evidence from Mexico", Journal of Political Economy, vol. 126, issue 1, 1 - 73

Baldwin, R, and R Freeman (2020), "Supply chain contagion waves: Thinking ahead on manufacturing 'contagion and reinfection' from the Covid concussion", VoxEU.org, 1 April 2020.

Baldwin, R. and J. Lopez-Gonzalez (2015), "Supply-chain Trade: A Portrait of Global Patterns and Several Testable Hypotheses," The World Economy, 38:1682-1721.

Borin, A. and M. Mancini (2015), "Follow the value added: bilateral gross export accounting", Banca d'Italia Working Papers (Temi di discussione) No. 1026, July.

Bourgeois, A. and A. Briand (2019), "Le 'made in France': 81\% de la consummation totale des ménages, mais 36\% seulement de celle des biens manufactures", Insee Première.

Breinlich, H. E., Dhingra, S., Sampson, T. and J. Van Reenen (2016), "Who Bears the Pain? How the costs of Brexit would be distributed across income groups", Centre for Economic Performance Brexit Analysis No. 07, London School of Economics.

Breinlich. H., E. Leromain. D. Novy and T. Sampson (2017), "The Brexit Vote. Inflation and UK Living Standards", Centre for Economic Performance Brexit Analysis No. 11, London School of Economics.

Burstein, A., Eichenbaum, M. and S. Rebelo (2005), "Large Devaluations and the Real Exchange Rate", Journal of Political Economy, 113(4), August, pp. 742-784.

Cappariello, R. and A. Felettigh (2015), "How Does Foreign Demand Activate Domestic Value Added? A Comparison Among the Largest Euro-area Economies", Banca d'Italia Working Papers (Temi di discussione) No. 1001.

Cravino. J. and A. A. Levchenko (2017), "The distributional consequences of large devaluations", NBER Working Paper No. 23409.

Deaton, A. and J. Muellbauer (1980), “An Almost Ideal Demand System”, American Economic Review, 70: 312-326.

Fajgelbaum, P., G. M. Grossman and E. Helpman (2011), "Income Distribution, Product Quality, and International Trade", Journal of Political Economy, 119(4), 721-765.

Fajgelbaum, P. D. and A. K. Khandelwal (2016), "Measuring the unequal gains from trade", Quarterly Journal of Economics, 131: 1113-1180.

Feenstra, R. C. and J. Romalis (2014), "International Prices and Endogenous Quality", Quarterly Journal of Economics, 129: 477-527.

Gopinath, G. (2015), “The International Price System”, NBER working paper n. 21646.

Hale, G. and B. Hobijn (2016). "Share of Imports and Commodities in Consumption and Investment in the United States". in Xing. Yuqing (ed.) Uncovering value added in trade new approaches to analyzing global value chains. World Scientific Publishing.

Hale G., Hobijn, B., Nechio, F. and D. Wilson (2019), "How Much Do We Spend on Imports?", FRBSF Economic Letter. 
Los, B., Timmer M. P. and G. J. De Vries (2016), "Tracing Value-Added and Double Counting in Gross exports: Comment”, American Economic Review, 106(7): 1958-1996.

Koopman, R., Wang, Z. and S. Wei (2014), “Tracing Value-Added and Double Counting in Gross Exports", American Economic Review, 104(2): 459-94.

Rondinelli, C. (2015), "Estimating demand elasticities in the recent crises", mimeo, paper presented at AIEL 2015. 